\title{
Possible use of struvite as an alternative phosphate fertilizer
}

\author{
Nqaba Nongqwenga ${ }^{1 *}$, Pardon Muchaonyerwa ${ }^{1}$, Jeffrey Hughes ${ }^{1}$, Alfred Odindo $^{2}$, Irene \\ Bame $^{1,3}$
}

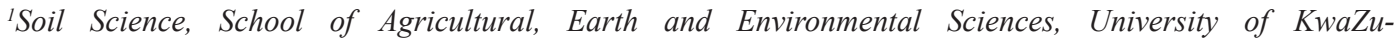
lu-Natal, Private Bag X01, Scottsville 3209, South Africa. ${ }^{2}$ Crop Science, School of Agricultural, Earth and Environmental Sciences, University of KwaZulu-Natal, Private Bag X01, Scottsville 3209, South Africa. ${ }^{3}$ Institute of Agricultural Research for Development (IRAD) Bambui, P.O Box 51 Bamenda, North West Region, Cameroon. *Corresponding author: nongqwengan@ukzn.ac.za

\begin{abstract}
Struvite, from human urine, is an alternative phosphorus (P) fertilizer. This study evaluated $\mathrm{P}$ release from struvite and its effectiveness for maize in Inanda (Ia), Sepane (Se) and Cartref (Cf) soils. Phosphorus sorption isotherms were determined, an incubation study determined the release pattern of $\mathrm{P}$ from struvite, and a pot trial compared struvite with single superphosphate (SSP) on maize $\mathrm{P}$ uptake. The amount of $\mathrm{P}$ at equilibrium (where $\mathrm{Q}=0$ ) in the $\mathrm{Cf}$ was $1.39 \mathrm{mg} \mathrm{L}^{-1}$, followed by Ia and Se with values of 0.17 and $0.13 \mathrm{mg} \mathrm{L}^{-1}$, respectively. Buffer coefficients were in the order Ia $>\mathrm{Se}>\mathrm{Cf}$ with values of 454,71 and $50 \mathrm{mg} \mathrm{kg}^{-1} / \mathrm{mg} \mathrm{L}^{-1}$, respectively. The extractable $\mathrm{P}$ in all three soils increased with time, with evidence of declining P release after Day 8. Struvite was most effective as a P source in the Cf followed by Se and Ia. Compared to SSP, there was significant improvement in maize grown on the Cf, while the reverse occurred in the Se. Maize grown in the Ia did not respond to either struvite or SSP. It was concluded that the phosphorus sorption was the main limiting factor that governed struvite effectiveness as a $\mathrm{P}$ source.
\end{abstract}

Keywords: Phosphorus-sorption, struvite, urine, phosphate fertilizer.

\section{Introduction}

The use of human urine as a source of nutrients for crops has received considerable attention (Kutu et al., 2010; Akpan-Idiok et al., 2012). From these studies, urine has been shown to have potential as a source of both nitrogen $(\mathrm{N})$ and phosphorus $(\mathrm{P})$. Generally, crops fertilized with urine have an agronomic performance comparable to those fertilized with commercial mineral fertilizers. However, there is a social stigma and health concerns with the consumption of crops grown with human urine (Mugivhisa and Olowoyo, 2015). 
Cross contamination of urine by faecal matter has been a cause of great concern, with potential health hazards including the introduction of contaminants such as Escherichia coli and sterols into the food chain, and rotavirus infections (Hoglund et al., 2002). Separation of urine from faeces at source, has been shown to circumvent some of the health and cross contamination concerns (Karak and Bhattacharyya, 2011). Although Mugivhisa and Olowoyo (2015) found that $70 \%$ of 225 respondents were willing to change their attitude towards crops grown with human urine in South Africa, which suggested an increasing social acceptance there are still some logistical and technical challenges with handling human urine.

Handling costs (transportation and storage) of human urine remain challenging, due to the high amount of water and possible nutrient losses. Loss of nitrogen through ammonia volatilization, inconsistent nutrient concentrations and the heavy metal content of urine are also major concerns. Maurer, et al. (2006) extensively reviewed technologies for human urine treatment, with the major focus on volume reduction of source-separated urine, such as evaporation, reverse osmosis and precipitation of struvite (magnesium ammonium phosphate; $\left.\mathrm{MgNH}_{4} \mathrm{PO}_{4} \cdot 6 \mathrm{H}_{2} \mathrm{O}\right)$. Precipitation of struvite, by the addition of a magnesium salt to urine, is one of the options currently being evaluated to handle source-separated urine in South Africa.

Struvite is a potentially viable agronomic option due to its high and consistent nutrient composition (Uysal et al., 2010; Antonini et al., 2012), the 98\% reduction in original urine volume (Tilley et al., 2011), low pathogen and heavy metal content (Decrey et al., 2011) and the cost effectiveness of its production (Etter et al., 2011). Struvite contains $5.7 \%$ N, $12.6 \% \mathrm{P}$ and $9.9 \% \mathrm{Mg}$ by mass (Etter et al., 2011) and the high amount of $\mathrm{P}$ makes it a potential source of $\mathrm{P}$ for crops and its use could be particularly important in the future, considering that $\mathrm{P}$ reserves are a finite resource
(Schroder et al., 2009). Given that urine is ubiquitous, struvite production might mitigate some of these supply challenges.

Phosphorus is one of the most limiting nutrients for crop production, especially in tropical and sub-tropical regions and the production of struvite could thus be of particular importance. Considerable attention has been given to struvite production and process optimization. The agronomic value of struvite has also been evaluated and studies have shown that struvite can be as effective as commercial superphosphate, and under some circumstances can outperform it (Uysal et al., 2014). Uysal et al. (2010) have suggested that struvite effectiveness as a $\mathrm{P}$ fertilizer is favoured in soils with acidic $\mathrm{pH}$.

Despite a considerable number of studies that have been carried out to investigate the agronomic value of struvite, there is only limited information with regards to the role of soil properties on the effectiveness of struvite. The objectives of this study were therefore to investigate the effect of soil properties on struvite effectiveness as a P amendment; to evaluate the potential of struvite to supply plant available $P$ using maize as a test crop; and to compare struvite effectiveness as a $P$ source to that of a conventional $P$ fertilizer (single superphosphate).

\section{Materials and Methods}

\subsection{Soils and struvite}

Three contrasting soil horizons were used, namely the E horizon from a Cartref form (Cf; Typic Haplaquept), and the A horizon from an Inanda (Ia; Rhodic Hapludox) and a Sepane form (Se; Aquic Haplustalf) (Soil Classification Working Group, 1991; Soil Survey Staff, 2014; , respectively). The Cf was sampled from Otto's Bluff near Pietermaritzburg in KwaZulu-Natal (KZN) Province, South Africa $\left(29^{\circ} 56^{\prime} \mathrm{S}, 30^{\circ} 38^{\prime} \mathrm{E}\right)$ under natural grassland. The Ia was collected from 
World's View (29 $\left.57^{\prime} \mathrm{S}, 30^{\circ} 57^{\prime} \mathrm{E}\right)$, Pietermaritzburg under commercial forestry and the Se from a permaculture site at Newlands-Mashu (29 $\left.9^{\circ} 77^{\prime} \mathrm{S}, 30^{\circ} 99^{\prime} \mathrm{E}\right)$, near Durban, KZN. All soils were air-dried and sieved to pass a $2 \mathrm{~mm}$ mesh before analysis and use. Samples for organic carbon analysis were sieved to $<500 \mu \mathrm{m}$. Soil $\mathrm{pH}$ was determined in both water and $1 \mathrm{M} \mathrm{KCl}$ at a soil: solution ratio of 1:2.5 using a $\mathrm{pH}$ meter (PHM 210). The exchangeable acidity, acid saturation, exchangeable $\mathrm{Ca}, \mathrm{Mg}, \mathrm{K}$, and extractable $\mathrm{P}$ were determined using standard methods (The Non-Affiliated Soil Analysis Working Committee, 1990). Dithionitecitrate-bicarbonate (DCB; Mehra and Jackson, 1960) and acid ammonium oxalate (Jackson et al., 1986) extractable iron $\left(\mathrm{Fe}_{\mathrm{d}}, \mathrm{Fe}_{\mathrm{o}}\right)$ and aluminium $\left(\mathrm{Al}_{\mathrm{d}}, \mathrm{Al}_{\mathrm{o}}\right)$ were analysed by inductively coupled plasma-atomic emission spectroscopy (ICP-AES) using a Varian 720 ES. Soil texture was determined by the pipette method (Gee and Bauder, 1986), and organic carbon (OC) by dichromate oxidation (Walkley, 1947).

The struvite used in this study was produced by the addition of $\mathrm{MgCl}_{2}$ to human urine sourced from urine diversion toilets within the eThekwini (Durban) Municipality. Following struvite crystallization, the suspension was filtered, and the struvite retained on the filter was dried under ambient conditions for at least four days. Struvite was screened through a $2 \mathrm{~mm}$ mesh before use.

\subsection{Phosphorus adsorption isotherms}

Phosphorus adsorption on the three soils was studied using equilibration $\mathrm{P}$ concentrations of $0,5,10,20$, $40,80,100,140$ and $180 \mathrm{mg} \mathrm{P} \mathrm{L}^{-1}$ for the Ia and 0 , 2.5, 5.0, 7.5, 10, 12.5, 15 and $20 \mathrm{mg} \mathrm{P} \mathrm{L}^{-1}$ for the Se and $\mathrm{Cf}$. The $\mathrm{P}$ solution concentrations for the Ia were different due to its expected higher sorption characteristics. The P solutions were prepared by dissolving potassium dihydrogen phosphate in $0.01 \mathrm{M}$ calcium chloride. The soil suspensions (1: 10 soil to solution ratio) were shaken at $25^{\circ} \mathrm{C}$ on a reciprocating shaker for 16 hours and then left to equilibrate for 2 hours. The tubes were centrifuged at 12,000 rpm (Sorvall RC 5C; Heraeus; Model-930437) for $12 \mathrm{~min}$ and then filtered through a Whatman No. 1 filter paper (Rayment and Lyons, 2011). The extract was then analyzed for P using the molybdenum blue method (Murphy and Riley, 1962). The Langmuir linearized equation Equation (1) was found to be the best fit for the data compared to the Freundlich isotherm, and was used to derived sorption parameters.

$\frac{C}{Q}=\frac{1}{Q_{\max } \times b}+\frac{C}{Q_{\max }}$

where $\mathrm{C}$ is the equilibrium concentration $\left(\mathrm{mg} \mathrm{L}^{-1}\right)$; $\mathrm{Q}$ is the amount of $\mathrm{P}$ sorbed $\left(\mathrm{mg} \mathrm{kg}^{-1}\right)$; Qmax is the maximum amount of $\mathrm{P}$ that a soil can retain $\left(\mathrm{mg} \mathrm{kg}^{-1}\right)$; $\mathrm{a}$ and $\mathrm{b}$ are constants.

\subsection{Incubation study}

To assess P release from struvite $2 \mathrm{~kg}$ of each soil (Ia, $\mathrm{Se}$ and $\mathrm{Cf}$ ) was amended with four rates of powdered struvite $(<500 \mu \mathrm{m})$, each treatment replicated three times. The struvite application rates were $0,0.035$, 0.11 and $0.175 \mathrm{~g} \mathrm{~kg}^{-1}$ for Ia, $0,0.065,0.2$ and 0.39 $\mathrm{g} \mathrm{kg}^{-1}$ for Se and 0, 0.07, 0.21 and $0.42 \mathrm{~g} \mathrm{~kg}^{-1}$ for Cf. These were equivalent to $0,10,30$ and $50 \mathrm{~kg} \mathrm{ha}^{-1}$ for Ia, 0, 30, 90 and $180 \mathrm{~kg} \mathrm{ha}^{-1}$ for Se, and 0, 40, 120 and $240 \mathrm{~kg} \mathrm{ha}^{-1}$ for $\mathrm{Cf}$, and in the text are referred to as R0, R0.5, R1 and R2, respectively, for each soil. The rates chosen differ between the soils with $0,0.5,1.5$ and 2.5 times the recommended rate for maize (in pot trial) for Ia and 0, 0.5, 1.5 and 3 times for Se and Cf. This approach has been used by Warren et al. (2009) to study P release from animal bone-char. The higher 
rates than recommended for maize were used to be able to extract sufficient $\mathrm{P}$ to show the trends of the release with incubation.

The treated soil samples were wetted to $50 \%$ of their water holding capacity $50 \%$ was chosen so as to allow sufficient aeration, and ensure that moisture does not limit the dissolution of struvite (Warren et al., 2009) This was determined by saturating a subsample of known mass of each soil and allowing it to drain for 24 hours and reweighing, and then incubated at a constant temperature of $25^{\circ} \mathrm{C}$ for 22 days. Moisture correction was done weekly based on weight loss, and the containers with the treated soils were opened every three days to maintain aerobic conditions. Samples were taken on days $1,2,5,8,16$ and 22. At each sampling, $50 \mathrm{~g}$ of soil was removed from each container, air dried and sieved to pass a $2 \mathrm{~mm}$ mesh. After extraction with ammonium bicarbonate-EDTA (The Non-Affiliated Soil Analysis Work Committee, 1990), P was analysed by the molybdenum blue method (Murphy and Riley, 1962).

\subsection{Pot trial}

The experiment was conducted at the University of KwaZulu-Natal (UKZN), Pietermaritzburg Campus $\left(29^{\circ} 36^{\prime} \mathrm{S}, 30^{\circ} 23^{\prime} \mathrm{E}\right)$ under glasshouse conditions with maximum and minimum temperatures of $26^{\circ} \mathrm{C}$ and $16^{\circ} \mathrm{C}$, respectively. Struvite was mixed with 2 $\mathrm{kg}$ of each of the three soils (Ia, Se and Cf), which had been air-dried, milled and sieved $(<2 \mathrm{~mm})$. The struvite application rates were based on $\mathrm{P}$ requirements for maize which were 20, 60 and $80 \mathrm{~kg} \mathrm{P} \mathrm{ha}^{-1}$ for the Ia, Se and Cf, respectively, as recommended by the KwaZulu-Natal Department of Agriculture. These were equivalent to $0.20,0.40$ and $0.42 \mathrm{~g}$ of struvite per pot for the Ia, Se and Cf, respectively. The application rates for each soil were chosen so as to include no P (R0), half the recommended rate (R0.5) the recommended rate (R1) and twice the recommended rate (R2). Single superphosphate (SSP $10.5 \% \mathrm{P}$ ), was applied at the recommended rate for each soil.

After subtracting the amount of $\mathrm{N}$ applied as struvite the balance was applied as urea to meet the recommended $\mathrm{N}$ requirement of $200 \mathrm{~kg} \mathrm{ha}^{-1}$ for all three soils. Potassium $(\mathrm{KCl})$ was added at recommended rates equivalent to $205 \mathrm{~kg} \mathrm{~K} \mathrm{ha}^{-1}(0.35 \mathrm{~g}$ per pot) for Ia; $10 \mathrm{~kg} \mathrm{~K} \mathrm{ha}^{-1}$ ( $0.010 \mathrm{~g}$ per pot) for the Se; and 100 $\mathrm{kg} \mathrm{K} \mathrm{ha}^{-1}(0.085 \mathrm{~g}$ per pot) for the Cf. All treatments were replicated three times.

Eight seeds of maize (Zea mays), PAN 4P-767BR cultivar, were planted per pot. After two weeks the seedlings were thinned to four plants per pot. The amount of irrigation applied was based on pore volume calculations. Plants were watered daily (using tap water) to $75 \%$ of the pore volume. Water which drained through the pots was returned back to the soil surface.

Pesticides and herbicides were not used during the experiment, and weeding was done by hand. After six weeks growth, the plants were harvested by cutting at $1 \mathrm{~cm}$ above soil level, and dried at $70{ }^{\circ} \mathrm{C}$ to constant weight to determine dry matter yield. The dried samples were then ground and digested with concentrated nitric acid and analyzed for $\mathrm{N}, \mathrm{Ca}, \mathrm{Mg}, \mathrm{K}$ and $\mathrm{P}$ by the procedure of Riekert and Bainbridge (1998). Total $\mathrm{P}$ uptake was calculated from total dry matter and $\mathrm{P}$ concentration. After harvest, soil from each pot was air dried and analyzed for extractable $\mathrm{P}$, and exchangeable $\mathrm{Ca}$ and $\mathrm{Mg}$ (The Non-Affiliated Soil Analysis Work Committee, 1990).

\subsection{Statistical analysis}

Statistical analysis was performed using Genstat statistical software (Version 12.1; 2009). Analysis of variance (ANOVA) was conducted by running a full model across soils. Mean separation was done using the least significant difference (LSD) 
at $p=0.05$. Six contrasts were performed using application rates as contrasting factors, for both the incubation and pot trials. Factor levels which were contrasted in the pot trial were R0 vs R0.5, R0 vs R1, R0 vs R2, R0.5 vs R1, R0.5 vs R2, and R1 vs R2. The incubation experiment contrast was done within each soil and across all three soils. The contrast done across all three soils, assumed a similar structure for that adopted to contrast within soils, and similar factor levels were used.

\section{Results}

\subsection{Soil characteristics}

The properties of the three soils used in this study are given in Table 1. The Ia had the lowest $\mathrm{pH}$ and high acid saturation and $\mathrm{OC}$. The $\mathrm{Cf}$ had low clay and $\mathrm{OC}$ contents. The Se had a high concentration of exchangeable bases $(\mathrm{K}, \mathrm{Ca}$ and $\mathrm{Mg})$ and a near neutral $\mathrm{pH}\left(\mathrm{H}_{2} \mathrm{O}\right)$. Amounts of oxalate- and DCB-extractable $\mathrm{Fe}$ and $\mathrm{Al}$ were highest in the Ia and lowest in the Cf.

Table 1. Some physical and chemical properties of the three soils used

\begin{tabular}{|c|c|c|c|}
\hline Parameter & Inanda & Sepane & Cartref \\
\hline $\mathrm{pH}\left(\mathrm{H}_{2} \mathrm{O}\right)$ & 4.78 & 6.85 & 6.77 \\
\hline $\mathrm{pH}(\mathrm{KCl})$ & 3.82 & 5.47 & 4.83 \\
\hline Organic carbon $(\%)$ & 6.28 & 2.13 & 0.45 \\
\hline Sand $(\%)$ & 20 & 22 & 80 \\
\hline Silt (\%) & 48 & 43 & 12 \\
\hline Clay (\%) & 32 & 35 & 8 \\
\hline $\mathrm{Al}_{O}{ }^{\mathrm{a}}(\%)$ & 0.52 & 0.23 & 0.03 \\
\hline $\mathrm{Fe}^{\mathrm{a}}(\%)$ & 1.84 & 0.64 & 0.18 \\
\hline $\mathrm{Al}_{\mathrm{d}}^{\mathrm{b}}(\%)$ & 0.89 & 0.17 & 0.01 \\
\hline $\mathrm{Fe}_{\mathrm{d}}^{\mathrm{b}}(\%)$ & 2.95 & 1.84 & 0.26 \\
\hline $\mathrm{P}\left(\mathrm{mg} \mathrm{kg}^{-1}\right)$ & 1.50 & 0.50 & 0.50 \\
\hline $\mathrm{K}\left(\mathrm{cmol}_{\mathrm{c}} \mathrm{kg}^{-1}\right)$ & 0.10 & 0.27 & 0.12 \\
\hline $\left.\mathrm{Ca}\left(\mathrm{cmol}_{\mathrm{c}} \mathrm{kg}^{-1}\right)\right)$ & 0.52 & 10.26 & 1.76 \\
\hline $\mathrm{Mg}\left(\mathrm{cmol}_{\mathrm{c}} \mathrm{kg}^{-1}\right.$ & 0.48 & 8.60 & 0.82 \\
\hline Exch Acidity $\left(\mathrm{cmol}_{\mathrm{c}} \mathrm{kg}^{-1}\right)$ & 32.3 & 10.0 & 10.0 \\
\hline \multicolumn{4}{|c|}{$\underline{\text { Sorption parameters }}^{*}$} \\
\hline Qmax $\left(\mathrm{mg} \mathrm{kg}^{-1}\right)$ & 1666.66 & 344.82 & 172.41 \\
\hline $\mathrm{b}\left(\mathrm{l} \mathrm{kg}^{-1}\right.$ of $\left.\mathrm{P}\right)$ & 1.00 & 1.58 & 9.17 \\
\hline
\end{tabular}

a acid ammonium oxalate extractable; ${ }^{\mathrm{b}}$ dithionite-citrate-bicarbonate extractable.

* from the Langmuir isotherm equation

\subsection{Phosphorus sorption}

The P sorption isotherms are presented in Figure 1 and the sorption parameters are given in Table 1. The sorption maximum (Qmax) was highest in the Ia followed by Se and Cf. The amount of $\mathrm{P}$ adsorbed (Q) when $\mathrm{C}$ is 0 was highest in the Ia with a value of $793.12 \mathrm{mg} \mathrm{kg}^{-1}$, followed by Se (141.04 $\left.\mathrm{mg} \mathrm{kg}^{-1}\right)$ and $\mathrm{Cf}\left(16.76 \mathrm{mg} \mathrm{kg}^{-1}\right)$ (Figure 1). 


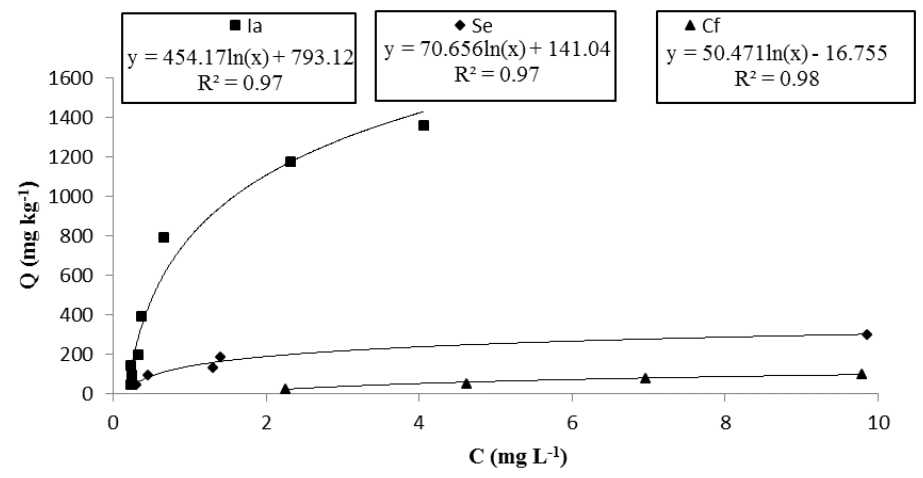

Figure 1. Phosphorus sorption isotherms of the Inanda (Ia), Sepane (Se) and Cartref (Cf) soils

The amount of $\mathrm{P}$ at equilibrium $(\mathrm{C})$ when $\mathrm{Q}=0$ was highest in the $\mathrm{Cf}$ soil with a value of $1.39 \mathrm{mg} \mathrm{L}^{-1}$, followed by Ia and Se with values of 0.17 and $0.13 \mathrm{mg}$ $\mathrm{P} \mathrm{L}^{-1}$, respectively. The change in equilibrium $\mathrm{P}$ concentration (buffer coefficient), as parameterized by the slope of the sorption curve, was highest in Ia with a value of $454 \mathrm{mg} \mathrm{kg}^{-1} / \mathrm{mg} \mathrm{L}^{-1}$ followed by Se and Cf with values of 71 and $50 \mathrm{mg} \mathrm{kg}^{-1} / \mathrm{mg} \mathrm{L}^{-1}$, respectively.

\subsection{Incubation experiment}

The extractable $\mathrm{P}$ in all three soils increased with time, with evidence of declining P response after Day 8 (Figure 2). The change in extractable $\mathrm{P}$ with time in the Ia was almost the same at all four application rates, with R2 having a slightly steeper slope of $\mathrm{P}$ concentration than the other rates (Figure 2). Nonetheless, after 22 days the cumulative $\mathrm{P}$ in the zero treatment of the Ia soil was approximately $29 \mathrm{mg} \mathrm{P} \mathrm{kg}^{-1}$, almost three times higher than in the Cf soil, and the trend was similar at all application rates.

In the Cf soil the individual curves were clearly distinguishable between the different struvite application rates, with slopes getting steeper with increasing struvite rate (Figure 2). A similar though somewhat less clear distinction between the curves was seen in the Se. At 16 and 22 days, the rate of $P$ release (slope) decreased, this being more pronounced in the $\mathrm{Cf}$ than in the other two soils.
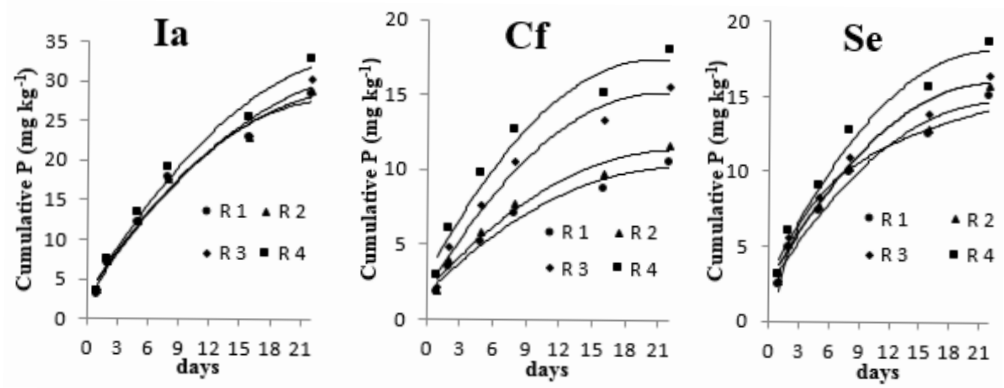

Figure 2. Cumulative phosphorus release patterns during the 22 day incubation period with different struvite application rates on Inanda (Ia), Sepane (Se) and Cartref (Cf) soils. R0 ( $0 \mathrm{~g} \mathrm{~kg}^{-1}$ in all soils), R0.5 (0.035, 0.065, $\left.0.07 \mathrm{~g} \mathrm{~kg}^{-1}\right)$; R1 $\left(0.11,0.2,0.21 \mathrm{~g} \mathrm{~kg}^{-1}\right)$, and R2 $\left(0.175,0.39,0.42 \mathrm{~g} \mathrm{~kg}^{-1}\right)$ for Ia, Se and Cf, respectively 
Comparing the different rates showed that there was no significant difference $(p>0.05)$ in soil $\mathrm{P}$ between the control and the lowest struvite P rate (R0.5) for all soils (Table 2). There was a significant difference between R0 (control) and R2 (highest application rate) and between R0.5 and R2 for all soils. Incubation time appeared to be the main factor affecting P release in the Ia soil $(p<0.001)$. For the $\mathrm{Cf}$ soil, additional significant relationships were found between $\mathrm{R} 0$ and $\mathrm{R} 1, \mathrm{R} 0.5$ and R1 ( $\mathrm{p}<0.001)$ and between R1 and R2 $(p<0.05)$. Amounts of $\mathrm{P}$ in the Se soil as affected by struvite rates showed fewer significant differences than on the $\mathrm{Cf}$ soil. In the Se, the P levels were highly significantly different $(p<0.001)$ between R0 and R2, R0.5 and R2, and R1 and R2 (Table 2).

Table 2. Statistical comparison of extractable phosphorus $(\mathrm{P})$ between different struvite rates from three different soils amended with four different rates $(\mathrm{R})$ of struvite during a 22-day incubation.

\begin{tabular}{cccccccc}
\hline Soil & $\mathrm{R} 0$ vs R0.5 & $\mathrm{R} 0$ vs R1 & $\mathrm{R} 0$ vs R2 & $\mathrm{R} 0.5$ vs R1 & $\mathrm{R} 0.5$ vs R2 & $\mathrm{R} 1$ vs R2 & P vs time \\
\hline Inanda & $\mathrm{ns}$ & $\mathrm{ns}$ & $* *$ & $\mathrm{~ns}$ & $*$ & $\mathrm{~ns}$ & $* * *$ \\
Cartref & $\mathrm{ns}$ & $* * *$ & $* * *$ & $* * *$ & $* * *$ & $*$ & $\mathrm{~ns}$ \\
Sepane & $\mathrm{ns}$ & $\mathrm{ns}$ & $* * *$ & $\mathrm{~ns}$ & $* * *$ & $* * *$ & $\mathrm{~ns}$ \\
\hline
\end{tabular}

ns - not significant, $* p<0.05, * * p<0.01, * * * p<0.001$

R0 (0 $\mathrm{g} \mathrm{kg}^{-1}$ in all soils), R0.5 (0.035, $\left.0.065,0.07 \mathrm{~g} \mathrm{~kg}^{-1}\right)$; R1 $\left(0.11,0.2,0.21 \mathrm{~g} \mathrm{~kg}^{-1}\right)$, and R2 $\left(0.175,0.39,0.42 \mathrm{~g} \mathrm{~kg}^{-1}\right)$ for Ia, Se and $\mathrm{Cf}$, respectively

\subsection{Pot trial}

Differences in soil type had a highly significant effect $(p<0.001)$ on maize biomass and nutrient uptake. In the Ia, struvite rates did not have a significant effect on maize biomass which was significantly lower than those of the other two soils (Table 3). The interaction between rates of struvite and soil type had a highly significant effect on the uptake of $\mathrm{P}$ by the maize. Phosphorus uptake in the $\mathrm{Cf}$ increased with struvite rate, while there was no response in the Se and Ia soils (Table 3). Struvite rates did not significantly affect $\mathrm{N}$ uptake in the Ia soil, whereas the R0.5 in the Cf and the R2 in the Se soil, the $\mathrm{N}$ uptake was significantly higher than at the zero application rates (R0).
Calcium uptake and biomass of maize were also significantly affected by the interaction of struvite rates and soil type (Table 3 ). Calcium, $\mathrm{Mg}$ and $\mathrm{K}$ uptake were significantly improved where struvite was applied in the $\mathrm{Cf}$ and Se soils, whereas struvite rate did not have an effect in the Ia soil (Table 4). It was also noted that the residual $\mathrm{P}, \mathrm{Ca}$ and $\mathrm{Mg}$ in all the soils after harvest, were not significantly affected by struvite rates (data not presented).

\subsection{Comparing struvite with single superphosphate}

Neither single superphosphate (SSP) nor struvite significantly affected biomass and nutrient uptake of maize grown in the Ia soil (Table 3 ). The source 
of $\mathrm{P}$ had a significant effect on the uptake of most nutrients and biomass on the other two soils $(p<$ 0.05 ) (Table 4). Phosphorus uptake was significantly higher in the SSP treated pots than struvite treated pots on the Se soil (Table 3).

On the Cf, P uptake from the SSP treatments was statistically similar to that of the control treatment.
The biomass of maize on the Se responded similarly to the P uptake. Also, the dry matter yields from the SSP treatments on the Cf were statistically similar to the zero application rate. Calcium and $\mathrm{Mg}$ uptake were improved on the Se when SSP was applied as a P sourcebut they were not statistically higher than from the struvite treated pots (Table 3 ).

Table 3. Mean comparison for uptake of phosphorus (P), magnesium $(\mathrm{Mg})$, calcium $(\mathrm{Ca})$, potassium $(\mathrm{K})$, nitrogen $(\mathrm{N})$ and maize biomass in three different soils amended with four different rates of struvite and single

\begin{tabular}{|c|c|c|c|c|c|c|}
\hline \multirow[t]{2}{*}{ Rate } & $\mathrm{P}$ & $\mathrm{Mg}$ & $\mathrm{Ca}$ & K & $\mathrm{N}$ & Biomass (g) \\
\hline & \multicolumn{6}{|c|}{ Uptake $\left(\mathrm{mg} \mathrm{pot}^{-1}\right)$} \\
\hline \multicolumn{7}{|c|}{$\underline{\text { Inanda }}$} \\
\hline R 0 & $2.23^{\mathrm{a}^{*}}$ & $1.15^{\mathrm{a}}$ & $0.887^{\mathrm{a}}$ & $6.54^{\mathrm{ab}}$ & $4.83^{\mathrm{ab}}$ & $2.33^{\mathrm{a}}$ \\
\hline R 0.5 & $2.12^{\mathrm{a}}$ & $1.12^{\mathrm{a}}$ & $0.908^{\mathrm{a}}$ & $8.14^{\mathrm{ab}}$ & $7.29^{\mathrm{abc}}$ & $2.36^{\mathrm{a}}$ \\
\hline R 1 & $2.68^{\mathrm{a}}$ & $1.09^{\mathrm{a}}$ & $1.061^{\mathrm{a}}$ & $8.66^{\mathrm{ab}}$ & $8.25^{\mathrm{abc}}$ & $2.90^{\mathrm{a}}$ \\
\hline $\mathrm{R} 2$ & $2.57^{\mathrm{a}}$ & $1.42^{\mathrm{ab}}$ & $1.07^{\mathrm{a}}$ & $8.49^{\mathrm{ab}}$ & $8.79^{\mathrm{abc}}$ & $2.73^{\mathrm{a}}$ \\
\hline SSP & $3.73^{\mathrm{a}}$ & $2.49^{\mathrm{ab}}$ & $1.64^{\mathrm{a}}$ & $7.87^{\mathrm{a}}$ & $7.79^{\mathrm{a}}$ & $3.6^{\mathrm{a}}$ \\
\hline \multicolumn{7}{|c|}{$\underline{\text { Cartref }}$} \\
\hline R 0 & $2.36^{\mathrm{a}}$ & $1.42^{\mathrm{ab}}$ & $1.18^{\mathrm{a}}$ & $5.48^{\mathrm{a}}$ & $3.08^{\mathrm{a}}$ & $2.66^{\mathrm{a}}$ \\
\hline R 0.5 & $7.4 b^{c}$ & $3.08^{\mathrm{abc}}$ & $2.71^{\mathrm{b}}$ & $24.5^{\mathrm{c}}$ & $15.2^{\mathrm{bcd}}$ & $7.83^{\mathrm{cd}}$ \\
\hline R 1 & $11.41^{\mathrm{c}}$ & $2.85^{\mathrm{ac}}$ & $2.67^{\mathrm{b}}$ & $8.4^{\mathrm{ab}}$ & $7.12^{\mathrm{abc}}$ & $7.23^{\mathrm{cd}}$ \\
\hline $\mathrm{R} 2$ & $23.14^{\mathrm{d}}$ & $3.35^{\mathrm{abc}}$ & $3.63^{\mathrm{b}}$ & $16.8^{\mathrm{bc}}$ & $8.56^{\mathrm{abc}}$ & $9.03^{\mathrm{d}}$ \\
\hline SSP & $6.69^{\mathrm{ab}}$ & $1.88^{\mathrm{a}}$ & $2.04^{\mathrm{a}}$ & $16.91^{\mathrm{a}}$ & $17.13^{\mathrm{ab}}$ & $6.53^{\mathrm{a}}$ \\
\hline \multicolumn{7}{|c|}{$\underline{\text { Sepane }}$} \\
\hline R 0 & $5.44^{\mathrm{ab}}$ & $2.05^{\mathrm{abc}}$ & $1.49^{\mathrm{a}}$ & $14.1^{\mathrm{abc}}$ & $10.40^{\mathrm{abc}}$ & $5.24^{\mathrm{b}}$ \\
\hline R 0.5 & $7.217^{\mathrm{bc}}$ & $4.347^{\mathrm{c}}$ & $2.89^{\mathrm{b}}$ & $19.87^{c}$ & $15.76^{\mathrm{cd}}$ & $6.84^{\mathrm{bc}}$ \\
\hline R 1 & $7.457^{\mathrm{bc}}$ & $4.323^{\mathrm{c}}$ & $3.23^{\mathrm{b}}$ & $15.84^{\mathrm{abc}}$ & $14.12^{\mathrm{bcd}}$ & $6.70^{\mathrm{bc}}$ \\
\hline $\mathrm{R} 2$ & $9.36^{\mathrm{bc}}$ & $3.769^{\mathrm{bc}}$ & $2.87^{\mathrm{b}}$ & $23.37^{\mathrm{c}}$ & $20.75^{\mathrm{d}}$ & $7.40^{\mathrm{cd}}$ \\
\hline SSP & $15.66^{\mathrm{c}}$ & $7.48^{\mathrm{b}}$ & $5.22^{\mathrm{b}}$ & $35.84^{\mathrm{b}}$ & $25.56^{\mathrm{b}}$ & $12.76^{\mathrm{b}}$ \\
\hline
\end{tabular}

* Values in the same column followed by the same letter are not significantly different $(p<0.05)$ according to Tukey's test R0 (0 $\mathrm{g} \mathrm{kg}^{-1}$ in all soils), R0.5 (0.035, 0.065, $\left.0.07 \mathrm{~g} \mathrm{~kg}^{-1}\right)$; R1 $\left(0.11,0.2,0.21 \mathrm{~g} \mathrm{~kg}^{-1}\right)$, and R2 $\left(0.175,0.39,0.42 \mathrm{~g} \mathrm{~kg}^{-1}\right)$ for Ia, Se and $\mathrm{Cf}$, respectively 
Table 4. Statistical comparison of phosphorus $(\mathrm{P})$, magnesium $(\mathrm{Mg})$, calcium $(\mathrm{Ca})$, potassium $(\mathrm{K})$, nitrogen (N) uptake and maize biomass in three different soils amended with four different rates of struvite and single superphosphate (SSP) in a pot trial

\begin{tabular}{ccccccc}
\hline & $\mathrm{P}$ & $\mathrm{Mg}$ & $\mathrm{Ca}$ & $\mathrm{K}$ & $\mathrm{N}$ & $\begin{array}{c}\text { Biomass }(\mathrm{g}) \\
\text { Factor }\end{array}$ \\
\cline { 2 - 6 } R0 vs R0.5 & $\mathrm{ns}$ & $*$ & $* * *$ & $* *$ & $*$ & $* * *$ \\
$\mathrm{R} 0$ vs R1 & $* *$ & $\mathrm{~ns}$ & $* * *$ & $\mathrm{~ns}$ & $\mathrm{~ns}$ & $* * *$ \\
$\mathrm{R} 0$ vs R2 & $* * *$ & $*$ & $* * *$ & $* *$ & $*$ & $* * *$ \\
$\mathrm{R} 0.5$ vs R1 & $\mathrm{ns}$ & $\mathrm{ns}$ & $\mathrm{ns}$ & $*$ & $\mathrm{~ns}$ & $\mathrm{~ns}$ \\
$\mathrm{R} 0.5$ vs R2 & $* * *$ & $\mathrm{~ns}$ & $\mathrm{~ns}$ & $\mathrm{~ns}$ & $\mathrm{~ns}$ & $\mathrm{~ns}$ \\
$\mathrm{R} 1$ vs R2 & $* * *$ & $\mathrm{~ns}$ & $\mathrm{~ns}$ & $\mathrm{~ns}$ & $\mathrm{~ns}$ & $\mathrm{~ns}$ \\
Soil & $* * *$ & $* * *$ & $* * *$ & $* * *$ & $* *$ & $* * *$ \\
Rate $\times$ Soil & $* * *$ & $\mathrm{~ns}$ & $*$ & $\mathrm{~ns}$ & $\mathrm{~ns}$ & $* *$ \\
SSP vs Struvite & $*$ & $\mathrm{~ns}$ & $*$ & $*$ & $*$ & $*$ \\
\hline
\end{tabular}

ns - not significant, $* p<0.05, * * p<0.01, * * * p<0.001$

$\mathrm{R} 0$ (0 $\mathrm{g} \mathrm{kg}^{-1}$ in all soils), R0.5 $\left(0.035,0.065,0.07 \mathrm{~g} \mathrm{~kg}^{-1}\right)$; R1 $\left(0.11,0.2,0.21 \mathrm{~g} \mathrm{~kg}^{-1}\right)$, and R2 $\left(0.175,0.39,0.42 \mathrm{~g} \mathrm{~kg}^{-1}\right)$ for Ia, Se and Cf, respectively

\section{Discussion}

Inanda had the highest $\mathrm{P}$ sorption this was due to high $\mathrm{Fe}$ and $\mathrm{Al}$ content (both $\mathrm{DCB}$ and oxalate-extractable), and low $\mathrm{pH}$ (Table 1). The high contents of $\mathrm{Fe}$ and $\mathrm{Al}$ oxides at low $\mathrm{pH}$ result in $\mathrm{P}$ fixation through the positively charged sites on the colloids. The lower P sorption of the Se than that of the Ia could be explained by its lower content of $\mathrm{Fe}$ and $\mathrm{Al}$ oxides and its higher $\mathrm{pH}$ (Fink et al., 2016). The sandy texture of the Cf explained the lower P sorption compared to the Ia and Se (Table 1; Figure 1).

Struvite effects on extractable $\mathrm{P}$ during incubation were highest on the Cf soil (Table 4). This is due to the low sorption properties of this soil (Table 1). A soil with low $\mathrm{P}$ sorption will poorly bind $\mathrm{P}$, and as such $\mathrm{P}$ will remain in labile form distributed between extractable form and soil solution. The Ia soil had the highest $\mathrm{P}$ sorption with $\mathrm{P}$ sorption maximum of $1666 \mathrm{mg} \mathrm{kg}^{-1}$, owing to this struvite had the lowest impact on extractable P on the Ia. In soils with high sorption maxima $\mathrm{P}$ released from a P source is fixed in an unavailable form on the oxides of $\mathrm{Al}$ and Fe through ligand exchange,, subsequently lowering the amount labile $\mathrm{P}$ as characterized by both extractable $\mathrm{P}$ and $\mathrm{P}$ in soil solution (Auxtero et al., 2008). In the Se, the impact of struvite was intermediate between the other two soils, Se had a a P sorption maximum of $344 \mathrm{mg} \mathrm{kg}^{-1}$ intermediate compared to that of Ia and Cf. The buffering capacity followed a trend which was similar to that of $\mathrm{P}$ sorption maxima, Ia had the highest buffering capacity followed by Se and $\mathrm{Cf}$, respectively. A soil with high $\mathrm{P}$ buffering capacity, will require more struvite to change the soil solution P concentration (Shirvani et al., 2005). The $\mathrm{P}$ buffering capacity results and the impact on extractable P under struvite treatments complements sorption maximum results. 
Struvite significantly improved maize $\mathrm{P}$ uptake and biomass, except on the Ia soil. Biomass and P uptake were most improved on the $\mathrm{Cf}$, followed by the $\mathrm{Se}$ and Ia soils the trends observed herein were similar to those of incubation study. Hence, the pot trial results can be similarly attributed to the large sink for P in the Ia, as parameterized by $\mathrm{P}$ sorption, and the positive response of the $\mathrm{Cf}$ can be similarly attributed to its low $\mathrm{P}$ sorption capacity. These results suggest that the $\mathrm{P}$ released by struvite in the Ia is not available for uptake by maize but is fixed by the oxides of Fe and $\mathrm{Al}$ especially in the Ia soil.

The comparison between struvite and SSP showed that struvite had an inconsistent performance across different soils. In the Se SSP outperformed struvite, while the reverse was true on the $\mathrm{Cf}$ soil and on the Ia no response was observed from either SSP or struvite (Table 3). The inconsistent performance of struvite has been reported before by Ackerman et al. (2013) and Massey et al. (2009) they both concluded that struvite effectiveness as a P fertilizer is dependent on soil properties. This proposition is in agreement with the results obtained on this study. Soil $\mathrm{pH}$ has been cited as the major factor that explain the variance of struvite effectiveness as a P fertilizer across different soils. It has been proposed that in acidic soils struvite solubility is enhanced, and the reverse is true for soils with high pH. (Massey et al., 2009; Ackerman et al., 2013). However, from the present study there is little evidence in support of soil $\mathrm{pH}$ as the main soil parameter that affects struvite $\mathrm{P}$ release and availability across different soils (Mehrizi et al., 2015; Palma et al., 2015). Both Se and Cf had a similar $\mathrm{pH}$ of 6.85 and 6.77 respectively, yet maize P uptake and biomass under struvite treatments were significantly lower compared to the SSP treatment in Se, while the reverse was true in Cf. The results suggests a compromised effectiveness of struvite in Se soil. It is worth noting that both struvite and SSP were applied to achieve similar P rates, so as to be able to make fair comparison between the two sources. The phosphorus sorption properties will impact $\mathrm{P}$ from both struvite and SSP similar manner, although some modifications on soils treated with struvite might occur due to the changes in salt concentration. Nonetheless, according to the study by Huang et al. (2015), changing ionic strength from $0.001 \mathrm{M}$ to $0.1 \mathrm{M}$ can cause a reduction in sorption maxima by up to $0.076 \mathrm{mg} \mathrm{g}^{-1}$, thus these modifications can be considered negligible in the present context. Furthermore, a reduction in sorption maximum is concurrent with an increase in soil solution P. This is contrary to the observation made on the Se, where P uptake and biomass were lower, compared to those of SSP, even on treatments where struvite was applied at twice the recommended rate. To explain these results we considered struvite dissolution as represented by Equation 2;

$\mathrm{MgNH}_{4} \mathrm{PO}_{4} 6 \mathrm{H}_{2} \mathrm{O} \rightleftharpoons \mathrm{Mg}^{2+}+\mathrm{NH}_{4}^{+}+\mathrm{PO}_{4}^{3-}+6 \mathrm{HO}$

Applying the solubility-product principle struvite dissolution will be limited in soils with high initial $\mathrm{P}$ and/ or $\mathrm{Mg}$ concentration, as these are the products of dissolution. The exchangeable $\mathrm{Mg}$ levels of Se and $\mathrm{Cf}$ were 8.60 and $0.80 \mathrm{cmol}_{\mathrm{c}} \mathrm{kg}^{-1}$ respectively, thus $\mathrm{Mg}$ levels in Se was more than 10 times higher to that of Cf. Therefore, higher concentration of $\mathrm{Mg}^{2+}$ in the Se than the $\mathrm{Cf}$ is the reason for lower P release from struvite in the Se soil, owing to the limited dissolution of struvite as explained by solubility product principle (Table 2; Figure 2) and the reverse applies on the Cf. It has been reported previously that high P levels can limit phosphate rock dissolution (Smyth and Sanchez, 1981; Uwumarongie-1lori et al., 2012). This might also apply to struvite in the Ia given its high initial $\mathrm{P}$ concentration and perhaps explain the poor response of crops to $\mathrm{P}$ in the Ia. (Table 1). Both low initial exchangeable $\mathrm{Mg}$ and extractable $\mathrm{P}$ in the 
Cf might explain the greater response to the added $\mathrm{P}$ from struvite, thus suggesting that struvite may be effective as a P source on this soil. The Cf soil seemed to be reaching equilibrium with struvite after 8 days in the incubation experiment, as suggested by declining P levels on Days 16 and 22 (Figure 2). The solubility of struvite is not the limiting factor for struvite dissolution given a short equilibration period between soils and struvite. Equilibrium between soil solution and struvite driven by the solubility product principle are the major driving forces of struvite dissolution under these experimental conditions.

\section{Conclusions}

This study investigated the potential of struvite as a $\mathrm{P}$ source for maize in three contrasting soils. Soil properties likely to affect $\mathrm{P}$ released by struvite were quantified. Struvite P release patterns revealed that it reaches equilibrium with all three soils within 10 days of incubation and thus P released by struvite can be considered readily available. The effectiveness of struvite as a P source for maize was compared to SSP and was found to be soil specific It was most effective on the sandy Cf soil that had low extractable Fe and $\mathrm{Al}$, and a low P sorption maximum. Solubility product principles pertaining to struvite dissolution need further investigation and of particular interest are the effects of initial soil levels of $\mathrm{Mg}$ and $\mathrm{P}$ on struvite dissolution. It is clear from the current study that struvite will be most effective in soils with low initial $P$, $\mathrm{Mg}$ and sorption maxima.

\section{Acknowledgements}

We express sincere appreciation to the members of the Pollution Research Group in the Discipline of Chemical Engineering at the University of KwaZulu-Natal, Durban Campus for their support and for supplying the struvite. We are grateful for the support from the Fertilizer Advisory Service in the Department of Agriculture, Forestry and Fisheries (KwaZulu-Natal) and for the analytical results of plant tissue material.

This study was funded by the College of Agriculture, Engineering and Science of the University of KwaZulu-Natal.

\section{References}

Ackerman, J.N., Zvomuya, F., Cicek, N., Flaten, D. 2013. Evaluation of manure-derived struvite as a phosphorus source for canola. Canadian Journal of Plant Sciences. 93, 419-424.

Akpan-Idiok, A., Udo, I.A., Braide, E.I. 2012. The use of human urine as an organic fertilizer in the production of okra (Abelmoschus esculentus) in South Eastern Nigeria. Resources Conservation and Recycling. 62, 14-20.

Antonini, S., Arias, M.A., Eichert, T., Clemens, J. 2012. Greenhouse evaluation and environmental impact assessment of different urine-derived struvite as phosphorus sources for plants. Chemosphere. 89, 1202-1210.

Auxtero, E., Madeira, M., Sousa, E. 2008. Phosphorus sorption maxima and desorbability in selected soils with andic properties from the Azores, Portugal. Geoderma. 144, 535-544.

Decrey, L., Udert, K.M., Tilley, E., Percson, B.M., Kohn, T. 2011. Fate of the pathogen indicators phage $\phi$ X174 and Ascaris suum eggs during the production of struvite fertilizer from sourceseparated urine. Water Research. 45, 4960-4972.

Etter, B., Tilley, E., Khadka, R., Udert, K.M. 2011. Lowcost struvite production using source-separated urine in Nepal. Water Research. 45, 852-862.

Fink, J.E., Inda, A.V., Tiecher, T., Barron, M. 2016. Iron oxides and organic matter on soil phosphorus availability. Ciencia e Agrotecnologia. 40, 369-379. 
Gee, G.W., Bauder, J.W. 1986. Particle-size analysis. In Klute, A (ed). Methods of Soil Analysis. Part 1: Physical and Mineralogical Methods. 2nd Edition, SSSA, Madison, Wisconsin.

Hoglund, C., Stenstrom, T.A., Ashbolt, N. 2002. Microbial risk assessment of source-separated urine used in agriculture. Waste Management and Research. 20, 150-161.

Huang, W., Lu, Y., Li, J., Zheng, Z., Zhang, J., Jiang, X. 2015. Effect of ionic strength on phosphorus sorption in different sediments from a eutrophic plateau lake. Royal Society of Chemistry. 5, 79607-79615.

Jackson, M.L., Lim, C.H., Zelazny, L.W. 1986. Oxides, hydroxides and aluminosilicates. In Klute, A (ed). Methods of Soil Analysis. Part 1: Physical and Mineralogical Methods. 2nd Edition, SSSA, Madison, Wisconsin.

Karak, T., Bhattacharyya, P. 2011. Human urine as a source of alternative natural fertilizer in agriculture a flight of fancy or an achievable reality? Resources Conservation and Recycling. $55,400-408$

Kutu, F.R., Muchaonyerwa, P., Mnkeni, P.N.S. 2010. Complementary nutrient effects of separately collected human faeces and urine on the yield and nutrient uptake of spinach (Spinacia oleracea). Waste Management and Research. 29, 535-539.

Massey, M.S., Davis, J.G., Ippolito, J.A., Sheffield, R.E. 2009. Effectiveness of Recovered Phosphate as Fertilizers in Neutral and Slightly Alkaline Soils. Agronomy Journal. 101, 323-329.

Maurer, M., Pronker, W., Larsen, T.A. 2006. Treatment processes for source-separated urine. Water Research. 40, 3151-3166.

Mehra, O.P., Jackson, M.L. 1960. Iron oxide removal from soils and clays by a dithionite-citrate system buffered with sodium bicarbonate. Clay Minerals. $7,317-327$.
Mehrizi, M.H., Sarcheshmehpour, M., Ebrahimi, Z. 2015. The effects of some humic substances and vermicompost on phosphorus transformation rate and forms in a calcareous soil. Journal of Soil Science and Plant Nutrition. 15, 249-260.

Mugivhisa, L.L., Olowoyo, J.O. 2015. An assessment of university students and staff perceptions regarding the use of human urine as a valuable soil nutrient in South Africa. African Health Sciences. 15, 999-1010.

Murphy, J., Riley, J.P. 1962. A modified single solution method for the determination of phosphate in natural waters. Analytica Chimica Acta. 27, 3136.

Palma, G., Demanet, R., Jorquera, M., Mora, M.L., Briceño, G., Violante, A. 2015. Effect of $\mathrm{pH}$ on sorption kinetic process of acidic herbicides in a volcanic soil. Journal of Soil Science and Plant Nutrition. 15, 549-560.

Rayment, G.E., Lyons, D.J. 2011. Soil Chemical Methods Australasia CSIRO Publishing, Collingwood, Australia.

Riekert, S., Bainbridge, S. 1998. Analytical methods of the CEDARA plant laboratory. KwaZulu-Natal Department of Agriculture and Environmental Affairs, Pietermaritzburg.

Schroder, J.J., Cordell, D., Smit, A.L., Rosemarin, A. 2009. Sustainable use of phosphorus. Plant Research International Wageningen. Report 357.

Shirvani, S., Shariatmadari, H., Kalbasi, M. 2005. Phosphorus buffering capacity indices as related to soil properties and plant uptake. Journal of Plant Nutrition. 28, 537-550.

Smyth, T.J., Sanchez, P.A. 1981. Phosphate rock dissolution and availability in Cerrado soils as affected by phosphorus sorption capacity. Soil Science Society of America Journal. 46, 339-345.

Soil Classification Working Group. 1991. A taxonomic system for South Africa. Memoirs Agric. Natur. 
Res. of South Africa, No 15, Department of Agriculture and Development. Pretoria.

Soil Survey Staff. 2014. Keys to Soil Taxonomy. 12th Edition. United States Department of Agriculture, Natural Resources Conservation Service, Washington DC.

The Non-Affiliated Soil Analysis Work Committee. 1990. Handbook of standard soil testing methods for advisory purposes. Soil Science Society of South Africa. Pretoria.

Tilley, E., Gantenbein, B., Khadka, R., Zurbrugg, C., Udert, K. M. 2011. Social and economic feasibility of struvite recovery from urine at the community level Nepal. Paper presented at the International Conference on Nutrient Recovery from Wastewater Streams. London.

Uwumarongie-llori, E.G., Oviasogie, P.O., Aghimien, A.E. 2012. Evaluation of rock phosphatephosphorus sorption and release in basement complex soil cultivated to the oil palm. Journal of Agricultural Research and Development. 2, 70-76.
Uysal, A., Demir, S., Sayilgan, E., Eraslan, F., Kucukyumuk, Z. 2014. Optimization of struvite fertilizer formation from baker's yeast wastewater: growth and nutrition of maize and tomato plants. Environmental Science and Pollution Research. 21, 3264-3274.

Uysal, A., Yilmazel, Y. D., Demirer, G. N. 2010. The determination of fertilizer quality of the formed struvite from effluent of a sewage sludge anaerobic digester. Journal of Hazardous Materials. 181, 248-254.

Walkley, A. 1947. A critical examination of a rapid method for determining organic carbon in soils: effect of variations in digestion conditions and of organic soil constituents. Journal of Soil Science. $63,251-263$.

Warren, G.P., Robinson, J.S., Someus, E. 2009. Dissolution of phosphorus from animal bone char in 12 soils. Nutrient Cycling in Agroecosystems. $84,167-178$. 